\title{
Variation of Flavonoid Content Among Sweetpotato Accessions
}

\author{
Peter B. Ojong1, Victor Njiti, Zibao Guo, Ming Gao, Samuel Besong ${ }^{2}$, and Sandra L. Barnes ${ }^{3,4}$ \\ Center for Biotechnology and Genomics, Alcorn State University, 1000 ASU Drive \#330, Alcorn State, \\ MS 39096
}

\begin{abstract}
AdDitional INDEX words. Ipomoea batatas, breeding, flavonol, flavone, HPLC, antioxidants
Abstract. The objective of this study was to characterize and quantify five commonly occurring flavonoids (quercetin, luteolin, apigenin, myricetin, and kaempferol) in storage roots and leaves of 10 sweetpotato [Ipomoea batatas L. (Lam.)] accessions: SC1149, 'Excel', 'Vardaman', 'Hernandez', 'Picadito', 'Porto Rico', 'GA90-16', PI531116, NC98608 (Covington), and 'Beauregard' (B94-14-G2). The flavonoids were present in varying amounts (quercetin comprised greater than $79 \%$ and $55 \%$ of the mean flavonoid content in sweetpotato leaf and root samples, respectively) and were found to be more concentrated in the leaves $(0.65 \%$ to $2.76 \%$ dry weight) than in the storage roots $(0.27 \%$ to $1.69 \%$ dry weight). The results indicate significant variability in flavonoid content among different sweetpotato accessions, suggesting that there is the potential for genetic manipulation of sweetpotato to influence flavonoid content and profile through traditional breeding or biotechnological approaches.
\end{abstract}

Flavonoids are a group of low-molecular-weight polyphenolic compounds. There are more than 6000 naturally occurring flavonoids, many of which are common in higher plants (Harborne and Williams, 2000). The basic structure of flavonoids consists of 15 carbon atoms, two benzene rings joined by a linear three-carbon chain. There are six classes of flavonoids: flavonols, flavones, flavonones, catechins, isoflavones, and anthocyanins. Flavonols and flavones are more widely distributed in a variety of plants compared with the other classes of flavonoids. Kaempferol, quercetin, myricetin, and isorhamnetin (flavonols) and apigenin and luteolin (flavones) are the most common in plants. Flavonols and flavones are of particular importance because they possess antioxidant and free radical scavenging activity in food (Jovanovic et al., 1994; Rice-Evans et al., 1997). Many in vitro studies have been conducted on the cytotoxic effects of quercetin, apigenin, and luteolin (Huang et al., 1999; Markaverich et al., 1990; Menon et al., 1995). Such studies generally revealed that these molecules inhibited the proliferation of a wide variety of cancer cell lines. A small number of in vivo studies have been conducted and have shown mixed results (Caltagirone et al., 2000; Ferry et al., 1996). In some folk medicinal plants, flavonols and flavones are the active components; for example, Eucalyptus macrorrhyncha F. Muell ex. Benth leaves contain high amounts of quercetin, and Ginkgo biloba L. leaves contain high amounts of quercetin

Received for publication 16 July 2007. Accepted for publication 14 July 2008 . This research was supported by a grant from the USDA.

Submitted as part of thesis degree requirement for Peter B. Ojong.

We thank Todd Williams and Bob Drake from the University of Kansas Biochemical Research Service Laboratory for LCMSMS analysis; Robert Leard for assistance with acid hydrolysis; Deepak Bhatnagar, Frank Matta, and Girish Panicker for advice and careful editing of this manuscript; and Umesh Reddy for his role in building the initial biotech research infrastructure of the Biotechnology Center at Alcorn State University.

${ }^{1}$ Current address: Department of Pharmacology-MS 108, University of Kansas Medical Center, 3901 Rainbow Boulevard, Kansas City, KS 66160.

${ }^{2}$ Current address: Family and Consumer Sciences Department, Delaware State University, 1200N Dupont Highway, Dover, DE 19901

${ }^{3}$ Current address: Department of Chemistry and Physics, Alcorn State University, 1000 ASU Drive, Alcorn State, MS 39096.

${ }^{4}$ Corresponding author. E-mail: sbarnes@alcorn.edu. and kaempferol. These medicinal plants have been used to treat circulatory diseases (Anton, 1988). The absence of flavonoids from the diet does not produce abnormalities; therefore, they have not been classified as vitamins in the United States (Vickery et al., 1950). However, food components such as flavonoids have been associated with biological activities consistent with reduced risk of chronic diseases (Beecher, 1999; Hines, 1999; Rhodes and Price, 1999). It has been reported that flavonoids and other antioxidants in food and wine play an important role in preventing cancer and cardiovascular diseases (Jovanovic et al., 1994; Rice-Evans et al., 1997). Some flavonoids have even been known to possess antiviral, antibacterial, antifungal, and antiallergenic properties (Jaakola et al., 2004). The isoflavones found in soybean [Glycine $\max$ (L.) Merr.] and other leguminous plants are believed to reduce the risk of breast cancer (Gabor, 1981). Flavonoids are located in the cytoplasm and plastids and are stored in the superficial layers of plant tissue. In plants, flavonoids are known to protect against damage by ultraviolet beta (ultraviolet B) rays (Weisshaar and Jenkins, 1998; WinkeShirley, 2002). They contribute to fruit color, flavor, texture, and bitterness (Robards and Antolovich, 1997). In plants, colored flavonoids function as attractors of pollinators, antifeedants, and signal molecules in nitrogen-fixing bacteria (Peter et al., 1986). In some plant species, flavonoids are required for fertility (Burbulis et al., 1996). Researchers have begun breeding crops, including mandarin (Citrus reticulata Blanco) and tomato (Solanum lycopersicum L.), for enhanced flavonoid content (Colliver et al., 2002; Moriguchi et al., 2001) to improve the health benefits of these crops. Studies involving other crops have shown that flavonoid production is usually influenced by genotype and environmental factors (Bohm, 1987; Estiarte et al., 1999). Although studies have confirmed the presence of flavonoids in sweetpotato [U.S. Department of Agriculture (USDA) 2003], there has been no systematic study of natural flavonoid variability among different sweetpotato accessions and distribution within different parts of the plant. Sweetpotato breeding studies have mainly focused on producing high anthocyanin sweetpotato lines for use as functional foods as well as natural colorants for the food industry 
(Konczak-Islam et al., 2003). The objective of this study was to determine the variability and distribution of flavonoid content in leaf and storage root among 10 sweetpotato accessions of diverse genetic background. This information will be used to assist in the development of breeding strategies for content and profile of flavonoids in sweetpotato that would enhance its use as a functional food.

\section{Materials and Methods}

Preparation of Plant material. Sweetpotato accessions, selected to include those commonly grown in the southern United States and commonly used germplasm types tested in this study include: SC1149, 'Excel', 'Vardaman', 'Hernandez', 'Beauregard'(B94-14-G2), 'Picadito', 'Porto Rico', 'Covington' (NC98-608), 'GA90-16', and PI531116. 'Excel' was developed in South Carolina from 'Regal' in a polycross nursery in 1981. 'Vardaman' was developed in Mississippi from M97-4/HM 145. 'GA90-16' was developed in the United States from 'Hi Dry' in a polycross nursery in 1990. 'Beauregard' was developed in Louisiana in a polycross nursery that included 17 breeding lines. 'Porto Rico' was developed in North Carolina. 'Hernandez' was developed in Louisiana from L70-323 in a polycross nursery in 1981. 'Picadito' was collected from Cuba. SC1149 was developed in South Carolina. NC98-608 was developed in North Carolina. PI531116 was introduced from Nigeria. All sweetpotato materials are maintained by the Southern Regional Plant Introduction Station in Griffin, GA. Information on the materials was obtained from the Germplasm Resources Information Network (USDA, 1989, 1993a, 1993b, 1993c, 1993d, 1993e, 2000, 2004). Cuttings from the materials were planted on 11 Aug. 2004 in a randomized complete block design with two replications. The plot size was one row with 10 plants per row. The analysis consisted of pooled samples from several plants in the row. The plants were irrigated as needed and harvested $90 \mathrm{~d}$ after planting. Leaves and cubed roots were washed, towel-dried, freeze-dried, ground, and stored at $-20{ }^{\circ} \mathrm{C}$. The roots were ground in liquid nitrogen using a mortar and a pestle, whereas the leaves were ground and strained.

High-PERFORMANCE LIQUID CHROMATOGRAPHY ANALYSIS. Sweetpotato root and leaf samples (1 g) were hydrolyzed in $3.7 \% \mathrm{HCl}$ (Sigma Aldrich, St. Louis, MO) for $2.25 \mathrm{~h}$ at $90{ }^{\circ} \mathrm{C}$, protected by ultrahigh-purity-grade gas nitrogen (Blankenstein's Supplies and Equipment, Natchez, MS) according to a previously reported method (Hertog et al., 1992). Sample solutions were filtered using a $0.45-\mu \mathrm{m}$ mini-uniprep syringeless filter (Fisher-Scientific, Atlanta, GA). Three aliquots of $10 \mu \mathrm{L}$ each were injected into the high-performance liquid chromatography (HPLC) for analysis of the flavonoid content. All solvents were HPLC grade (Sigma Aldrich). Stock solutions of the standards apigenin, kaempferol, luteolin, quercetin, and myricetin (Sigma Aldrich) were prepared at a concentration of $1000 \mu \mathrm{g} \cdot \mathrm{mL}^{-1}$ in $\mathrm{CH}_{3} \mathrm{OH}$ and stored at $-20{ }^{\circ} \mathrm{C}$. Dilutions of standards at concentrations of 100,50 , and $1 \mu \mathrm{g} \cdot \mathrm{mL}^{-1}$ were also prepared in $\mathrm{CH}_{3} \mathrm{OH}$ for preparation of the standard curve. For apigenin, a concentration of $0.5 \mu \mathrm{g} \cdot \mathrm{mL}^{-1}$ was also included because of the lower relative amounts of apigenin in the roots. Regression values for standard curves were $\geq 0.997$ (data not shown). Replicate standard curves were prepared. A previously reported reversed-phase gradient HPLC method was used with modification in the temperature control (Wang and Huang, 2004).
Separation was performed using a model 430 Prostar HPLC system (Varian, Walnut Creek, CA). The mobile phase was prepared using $1 \%(\mathrm{v} / \mathrm{v})$ tetrahydrofuran in deionized distilled $\mathrm{H}_{2} \mathrm{O}$ and adjusted to $\mathrm{pH} 3.0$ with $\mathrm{H}_{3} \mathrm{PO}_{4}$. The flavonoids were separated using the following gradient: $30 \%(\mathrm{v} / \mathrm{v}) \mathrm{CH}_{3} \mathrm{CN}$ (acetonitrile) for $8 \mathrm{~min}, 100 \% \mathrm{CH}_{3} \mathrm{CN}$ for $3 \mathrm{~min}$, and $100 \%$ $\mathrm{CH}_{3} \mathrm{CN}$ for $4 \mathrm{~min}$. Separation was performed on a $5-\mu \mathrm{m}, 250 \times$ 4.6-mm, C-18 column (Phenomenex, Torrance, CA). The ultraviolet-visible detector wavelength, column temperature, and the flow rate were $270 \mathrm{~nm}, 30{ }^{\circ} \mathrm{C}$, and $1.2 \mathrm{~mL} \cdot \mathrm{min}^{-1}$, respectively.

LIQUID CHROMATOGRAPHY/MASS SPECTROMETRY/MASS SPECTROMETRY. Tandem mass spectra of standard and sample flavonoids were acquired on a Quattro Ultima triple quadrupole instrument (Micromass Ltd., Manchester, U.K.). The electrospray source block was kept at $80{ }^{\circ} \mathrm{C}$ and probe desolvation temperature was $200{ }^{\circ} \mathrm{C}$. Argon collision gas was set to attenuate the beam to $15 \%\left(8 \times 10^{-5} \mathrm{kPa}\right.$ on a gauge near the collision cell). The cone voltage and collision energy was $25 \mathrm{~V}$ and 22 electron volts, respectively. Multiple reaction monitoring $(\mathrm{MRM})$ of $\mathrm{MH}^{+}>153$ were with 0.1 -s dwell time. Product ion scans were acquired at $100 \mathrm{u}$ (unified atomic mass unit). Quadrupoles 1 and 3 were tuned to a resolution of $0.8 \mu$ full width at the half-height. The initial separations were performed on a model 2695 chromatograph (Waters, Milford, MA) equipped with a $2.1 \mathrm{~mm} \times 5-\mathrm{cm} \mathrm{C}-18$ column (Alltech, Deerfield, IL). Samples were prepared in $40 \%(\mathrm{v} / \mathrm{v})$ $\mathrm{CH}_{3} \mathrm{CH}_{2} \mathrm{OH}$ and $\mathrm{H}_{2} \mathrm{O}$ and $5 \mu \mathrm{L}$ of sample and standards were injected. The separation was carried out using the following gradient conditions: $60 \% \mathrm{H}_{2} \mathrm{O} / 40 \%(\mathrm{v} / \mathrm{v}) \mathrm{CH}_{3} \mathrm{OH}$ for $8 \mathrm{~min}$, $28 \% \mathrm{H}_{2} \mathrm{O} / 72 \%$ (v/v) $\mathrm{CH}_{3} \mathrm{OH}$ for $1 \mathrm{~min}, 5 \% \mathrm{H}_{2} \mathrm{O} / 95 \%(\mathrm{v} / \mathrm{v})$ $\mathrm{CH}_{3} \mathrm{OH}$ for $1 \mathrm{~min}$, and $60 \% / 40 \%(\mathrm{v} / \mathrm{v}) \mathrm{CH}_{3} \mathrm{OH}$ for $1 \mathrm{~min}$. Detection limits were improved by a factor of 3 to 5 by switching to large injection volumes $(20 \mu \mathrm{L})$ on a smaller column. The final HPLC separations were performed on a C-18 reverse phase column (Waters) $1 \mathrm{~mm}$ i.d. $\times 5 \mathrm{~cm}$ at a flow rate of $0.1 \mathrm{~mL} \cdot \mathrm{min}^{-1}$. The mobile phase composition was $\mathrm{A}: 99 \% \mathrm{H}_{2} \mathrm{O} /$ $1 \% \mathrm{CH}_{3} \mathrm{OH} / 0.08 \% \mathrm{CH}_{2} \mathrm{O}_{2}(\mathrm{v} / \mathrm{v})$ and $\mathrm{B}: 99 \% \mathrm{CH}_{3} \mathrm{OH} / 1 \% \mathrm{H}_{2} \mathrm{O} /$ $0.06 \% \mathrm{CH}_{2} \mathrm{O}_{2}(\mathrm{v} / \mathrm{v})$. The solvent gradient used was as follows: time in minutes (\% B by volume) 0 (1), 2 (1), 5 (20), 10 (50), 12 (95). The percent dry weight $(\% \mathrm{DW})$ of flavonoids in the leaf and root samples were calculated using the following formula: $\% \mathrm{DW}=\left(100 \times \mu \mathrm{g} \cdot \mathrm{mL}^{-1}\right.$ concentration $\times 100 \mathrm{~mL}$ solvent $\times 10^{-6}$ $\left.\mathrm{g} \cdot \mu \mathrm{g}^{-1}\right) / 1 \mathrm{~g}$ sample. The expression $10^{-6} \mathrm{~g} \cdot \mu \mathrm{g}^{-1}$ is a conversion factor used to convert micrograms to grams so that all units in the equation will cancel.

Analysis of variance was conducted using the General Linear Model of SAS (version 6; SAS Institute, Cary, NC). Means comparison among plants was conducted using the Duncan's multiple range test. Mean comparison between leaf and root flavonoid content was conducted using the least significance difference test at $\alpha=0.05$. Correlation coefficients were also determined using the PROC CORR function of the SAS statistical program.

\section{Results and Discussion}

Representative chromatograms ('Vardaman') for elution profiles of flavonoids from sweetpotato leaf and root extracts are given in Figure 1 and Figure 2, respectively. The elution order of flavonoids was myricetin retention time of $3.4 \mathrm{~min}$, luteolin retention time of $4.7 \mathrm{~min}$, quercetin retention time of 


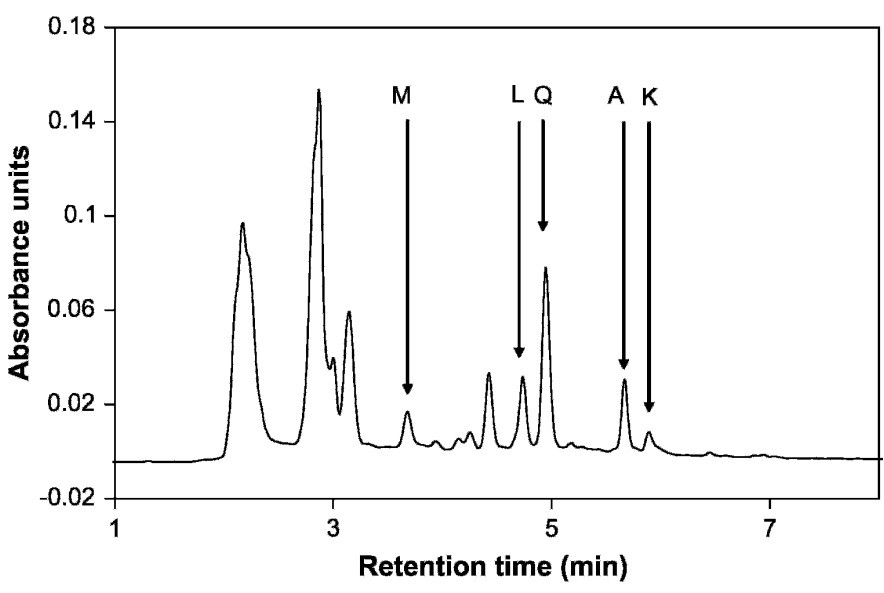

Fig. 1. Typical chromatogram of a leaf extract from 'Vardaman' sweetpotato accession obtained by acid hydrolysis and high-performance liquid chromatography analysis showing flavonoid peaks: $\mathrm{M}=$ myricetin, $\mathrm{L}=$ luteolin, $\mathrm{A}=$ apigenin, $\mathrm{K}=$ kaempferol, $\mathrm{Q}=$ quercetin.

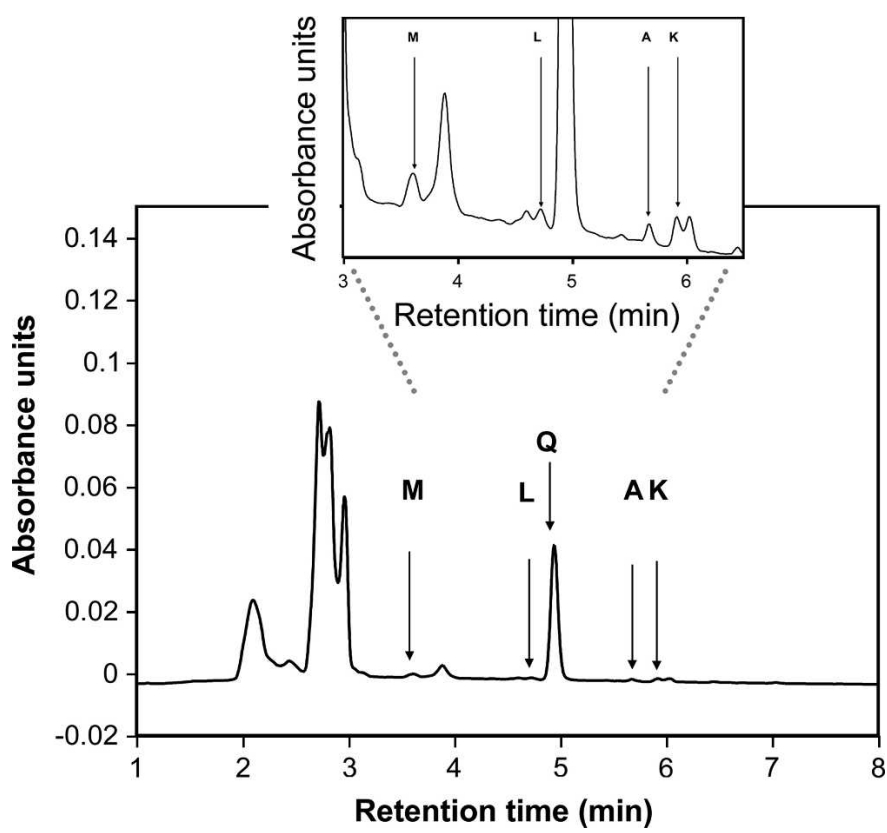

Fig. 2. Typical chromatogram of a root extract from 'Vardaman' sweetpotato accession obtained by acid hydrolysis and high-performance liquid chromatography analysis. The insert shows a more detailed view of smaller flavonoid peaks: $\mathrm{M}=$ myricetin, $\mathrm{L}=$ luteolin, $\mathrm{A}=$ apigenin, $\mathrm{K}=$ kaempferol, $\mathrm{Q}=$ quercetin.

$4.9 \mathrm{~min}$, apigenin retention time of $5.7 \mathrm{~min}$, and kaempferol retention time of $5.9 \mathrm{~min}$. Peak identities of flavonoids found in sweetpotato samples were confirmed by comparison of the sample data to the retention time and liquid chromatography/ mass spectrometry/mass spectrometry spectra of authentic flavonoid standards as well as those reported earlier (Borges et al., 2001; Kachlicki et al., 2005). Product ion scans from infusion of standard myricetin $\left(\mathrm{MH}^{+} 318\right)$, luteolin $\left(\mathrm{MH}^{+} 287\right)$, apigenin $\left(\mathrm{MH}^{+} 271\right)$, quercetin $\left(\mathrm{MH}^{+} 287\right)$, and kaempferol $\left(\mathrm{MH}^{+} 287\right)$ revealed a common fragment ion at $\mathrm{m} / \mathrm{z} 153$. Kaempferol also had an abundant product ion at $\mathrm{m} / \mathrm{z} 121$, which was used to distinguish it from closely eluting apigenin during liquid chromatography/MRM experiments. Peaks with retention times at $\approx 3$ minutes were observed in both leaf and root extracts. These peaks were relatively large compared with the flavonoid peaks identified. It is possible that these peaks could be the result of small organic molecules such as caffeic acid and/or other flavonoids such as catechin and epicatechin, which both elute near the void volume (S. Barnes, unpublished data; Wang and Huang, 2004).

Quercetin was the most abundant flavonoid present in all extract samples, comprising $55 \%$ to $79 \%$ of the total detected. With few exceptions, leaf samples contained more individual and total flavonoids than root samples (Tables 1, 2, and 3). When averaged across all plants, the total flavonoid content of the leaf was $1.79 \%$ DW compared with $0.80 \%$ DW in the storage root (Table 1). Highly significant variations in total flavonoid content were observed in the sweetpotato leaf and storage root. The total flavonoid content in the storage root ranged from $0.24 \% \mathrm{DW}$ to $1.69 \% \mathrm{DW}$ in 'Beauregard' and PI53116, respectively (Table 2). In the leaf, the total flavonoid content ranged from $0.64 \%$ DW to $2.77 \%$ DW in 'GA90-16' and 'Hernandez', respectively (Table 3 ). In all the accessions analyzed, quercetin was the most abundant flavonoid in both the leaf and storage root of sweetpotato (Tables 1, 2, and 3). This is consistent with previous reports in other plants such as bilberry (Vaccinium myrtillus L.), apple (Malus domestica Borkh.), and romaine lettuce (Lactuca sativa L.) (Harnly et al., 2006; Jaakola et al., 2004).

Formation of flavonoids have been shown to be lightdependent. In addition, higher amounts of flavonoids may be required in the leaf for protection against environmental stresses (Jaakola et al., 2004; Winke-Shirley, 2002). It has been observed that leaves exposed to solar radiation will turn red resulting from increased accumulation of flavonoids to protect the leaves from ultraviolet B rays as a result of their ability to absorb light (Jaakola et al., 2004; Winke-Shirley, 2002).

It has been reported that color intensity is a good predictor of the amount of flavonoids with darker color indicating higher flavonoid content (Weisshaar and Jenkins, 1998); however, in our study, PI53116, a light skin and white flesh plant, had significantly higher total flavonoid in the storage root than other plants with darker flesh color (Table 2). Besides chlorophyll, plant colors are primarily as a result of flavonoids and carotenoids. The latter is mostly responsible for the cream, yellow, and orange color in sweetpotato roots, mainly as a result of beta-carotene (Woolfe, 1992). Flavonoids may appear colored or colorless in nature. Among the thousands of flavonoids that occur in plants, only a few hundred appear in the colored state in nature. Anthocyanins are the most intensely colored flavonoid pigments, appearing red, purple, or blue in sweetpotato (Woolfe, 1992). Interestingly, anthocyanins may appear colorless or may exhibit copigmentation resulting from interaction with colorless or colored flavonoids, metals, or carotenoids (Brouillard and Cheminat, 1988). Because of the complexity of flavonoid interactions with each other as well as with other substances, it is difficult to predict flavonoid content based on color alone. In-depth quantitative analysis of different pigments, including different flavonoid classes, carotenoids, and metals, would be necessary for such a determination.

Although most accessions accumulated more flavonoids in the leaf rather than in the storage root, some such as PI53116 accumulated significantly more flavonoids in the storage root. Based on this observation, there might be genotype differences 
Table 1. Mean variation in flavonoid content as percent dry weight (\% DW) in leaf and storage root among 10 sweetpotato accessions: 'Beauregard', 'Excel', 'GA90-16', 'Hernandez', NC98-608, 'Picadito', PI53116, 'Porto-Rico', SC1149, and 'Vardaman'.

\begin{tabular}{lcccrr}
\hline Plant organ & \multicolumn{5}{c}{ Flavonoid content ${ }^{\mathrm{z}}(\% \mathrm{DW})^{\mathrm{y}}$} \\
\cline { 2 - 6 } analyzed & Quercetin & Myricetin & Luteolin & Apigenin & Kaempferol \\
\hline Leaf & $0.98 \mathrm{a}^{\mathrm{x}}$ & $0.12 \mathrm{a}$ & $0.23 \mathrm{a}$ & $0.38 \mathrm{a}$ & $0.07 \mathrm{a}$ \\
Storage root & $0.68 \mathrm{a}$ & $0.09 \mathrm{a}$ & $0.01 \mathrm{~b}$ & $0.00 \mathrm{~b}$ & $0.01 \mathrm{~b}$ \\
\hline
\end{tabular}

${ }^{\mathrm{z}}$ Sweetpotato samples were subjected to acid hydrolysis followed by analysis of flavonoid content using high-performance liquid chromatography.

у\% $\mathrm{DW}=\left(100 \times \mu \mathrm{g} \cdot \mathrm{mL}^{-1}\right.$ concentration $\times 100 \mathrm{~mL}$ solvent $\left.\times 10^{-6} \mathrm{~g} \cdot \mu \mathrm{g}^{-1}\right) / 1 \mathrm{~g}$ sample.

${ }^{\mathrm{x}}$ Means in the same column carrying the same letter were not significantly different when compared by least significant difference at $P=0.05$.

Table 2. Flavonoid accumulation as percent dry weight $(\% \mathrm{DW})$ in the root of nine sweetpotato accessions.

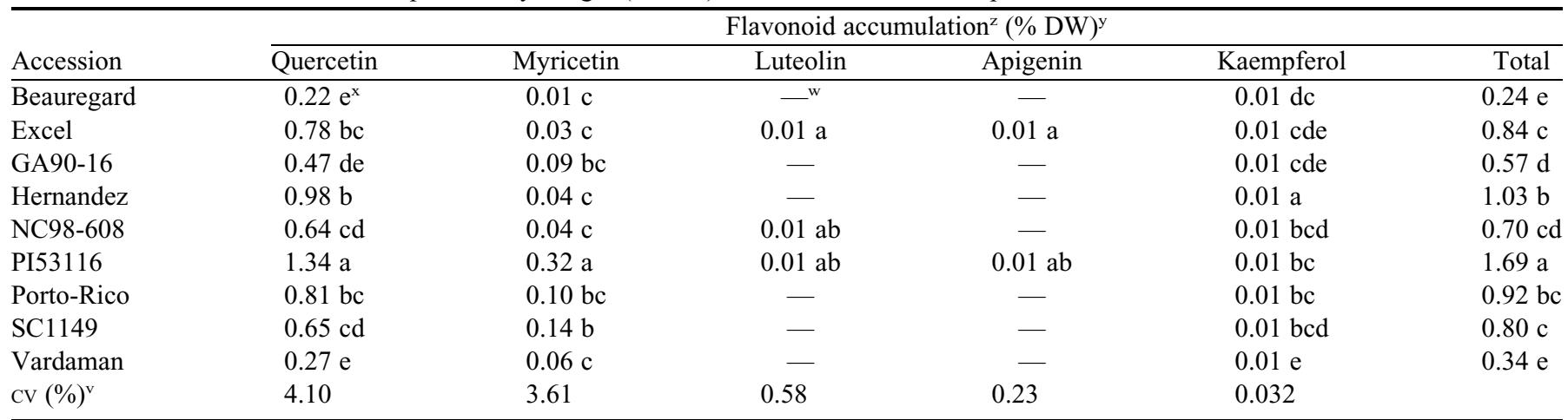

${ }^{\mathrm{z}}$ Sweetpotato leaf samples were subjected to acid hydrolysis and then the flavonoid content was analyzed by high-performance liquid chromatography.

у\% $\mathrm{DW}=\left(100 \times \mu \mathrm{g} \cdot \mathrm{mL}^{-1}\right.$ concentration $\times 100 \mathrm{~mL}$ solvent $\left.\times 10^{-6} \mathrm{~g} \cdot \mu \mathrm{g}^{-1}\right) / 1 \mathrm{~g}$ sample.

${ }^{x}$ Means in the same column followed by the same letter are not significantly different. Means were compared by Duncan's multiple range test at $P \leq 0.05$.

${ }^{\mathrm{w}}$ Dashes indicate no detection.

${ }^{\mathrm{v}} \mathrm{CV}=$ coefficient of variation.

Table 3. Flavonoid accumulation as percent dry weight (\% DW) in the leaf of nine sweetpotato accessions.

\begin{tabular}{lccccc}
\hline & \multicolumn{5}{c}{${\text { Flavonoid accumulation }{ }^{\mathrm{z}}(\% \mathrm{DW})^{\mathrm{y}}}$} \\
\cline { 2 - 5 } Accession & Quercetin & Myricetin & Luteolin & Apigenin & Kaempferol \\
\hline Beauregard & $0.80 \mathrm{c}^{\mathrm{x}}$ & $0.03 \mathrm{~d}$ & $0.28 \mathrm{ab}$ & $0.14 \mathrm{~d}$ & $0.14 \mathrm{a}$ \\
Excel & $1.43 \mathrm{a}$ & $0.16 \mathrm{bc}$ & $0.18 \mathrm{~d}$ & $0.60 \mathrm{~b}$ & $0.07 \mathrm{~cd}$ \\
GA90-16 & $0.30 \mathrm{~d}$ & $0.01 \mathrm{~d}$ & $0.25 \mathrm{bc}$ & $0.08 \mathrm{~d}$ & $2.44 \mathrm{~b}$ \\
Hernandez & $1.39 \mathrm{a}$ & $0.22 \mathrm{~b}$ & $0.27 \mathrm{~b}$ & $0.86 \mathrm{a}$ & $0.03 \mathrm{e}$ \\
PI53116 & $0.71 \mathrm{c}$ & $0.11 \mathrm{dc}$ & $0.34 \mathrm{a}$ & $0.12 \mathrm{~d}$ & $2.77 \mathrm{a}$ \\
Porto-Rico & $1.50 \mathrm{a}$ & $0.14 \mathrm{bc}$ & $0.27 \mathrm{~b}$ & $0.05 \mathrm{de}$ & $0.10 \mathrm{de}$ \\
SC1149 & $1.22 \mathrm{~b}$ & $0.33 \mathrm{a}$ & $0.17 \mathrm{~d}$ & $0.53 \mathrm{~b}$ & $2.54 \mathrm{~b}$ \\
Vardaman & $0.77 \mathrm{c}$ & $0.10 \mathrm{dc}$ & $0.21 \mathrm{dc}$ & $0.54 \mathrm{~b}$ & $0.10 \mathrm{~b}$ \\
Picadito & $0.70 \mathrm{c}$ & $0.01 \mathrm{~d}$ & $0.09 \mathrm{e}$ & $0.38 \mathrm{c}$ & $0.10 \mathrm{bc}$ \\
CV (\%) & 70.9 & 5.17 & 1.05 & $0.14 \mathrm{~d}$ & $0.06 \mathrm{de}$ \\
\hline
\end{tabular}

${ }^{2}$ Sweetpotato leaf samples were subjected to acid hydrolysis and then the flavonoid content was analyzed by high-performance liquid chromatography.

у\% $\%$ DW $=\left(100 \times \mu \mathrm{g} \cdot \mathrm{mL}^{-1}\right.$ concentration $\times 100 \mathrm{~mL}$ solvent $\left.\times 10^{-6} \mathrm{~g} \cdot \mu \mathrm{g}^{-1}\right) / 1 \mathrm{~g}$ sample.

${ }^{x}$ Means in the same column followed by the same letter are not significantly different. Means were compared by Duncan's multiple range test $(P \leq 0.05)$.

wDashes indicate no detection.

${ }^{\mathrm{v}} \mathrm{CV}=$ coefficient of variation.

in the amount of flavonoids needed for ultraviolet B protection in the leaf. When averaged across all plants, kaempferol was the least flavonoid detected in the leaf (Table 3). In addition, the amount of kaempferol in the storage root was $\approx 10$ times lower than in the leaf (Table 2). The low relative accumulation of kaempferol in both the leaf and storage root may have resulted from its conversion to quercetin and myricetin, because dihydrokaempferol has been reported to be a precursor of dihydroquercetin and dihydromyricetin (Jaakola et al., 2004).

The significant variation in flavonoid content among the sweetpotato accessions included in this study indicates that the 
flavonoid content and profile can potentially be manipulated through conventional breeding and/or molecular biotechnological approaches. This will facilitate the development of sweetpotatoes with high flavonoid content so that this crop can be used for preparation of various functional foods to fight against major diseases such as cancer and cardiovascular disease. The finding that the sweetpotato leaf had more flavonoids than the storage root also provides nutritionists with the option of incorporating the sweetpotato leaf into the human diet or animal feeds. The customary practices in some countries in Africa and Asia is to consume both the leaf and storage root of the sweetpotato, but in the United States, only the storage root is consumed, and this could change. The findings from this study will also lay the foundation for breeding and molecular mapping of chromosomal regions that underlie flavonoid accumulation in sweetpotato. For example, PI53116 is being crossed to an adapted orange flesh type and the progeny will be evaluated to identify potential plants with high flavonoid content. Double haploids will be developed from these progeny and used to identify loci controlling flavonoid accumulation in sweetpotato.

\section{Literature Cited}

Anton, R. 1988. Flavonoids and traditional medicine, p. 423-439. In: Cody, V., E. Middleton, Jr., J. Harborne, and A. Beretz (eds.). Plant flavonoids in biology and medicine. III: Biochemical, cell and medicinal properties. Liss, New York, NY.

Beecher, G.R. 1999. Phytonutrients' role in metabolism: Effects on resistance to degenerative processes. Nutr. Rev. 9:S3-S6.

Bohm, B.A. 1987. Intraspecific flavonoid variation. Bot. Rev. 53:197279.

Borges, C., P. Martinho, A. Martins, A.P. Rauter, and M.A. Almoster Ferreira. 2001. Structural characterization of flavonoids and flavonoido-glycosides extracted from Genista tenera by fast atom bombardment tandem mass spectrometry. Rapid Commun. Mass Spectrom. $15: 1760-1767$.

Brouillard, R. and A. Cheminat. 1988. Flavonoids and plant color, p. 93-106. In Cody, V., E. Middleton, Jr., J. Harbone, and A. Beretz (eds.). Plant flavonoids in biology and medicine. III: Biochemical, cellular, and medicinal properties. Liss, New York, NY.

Burbulis, I.E., M. Lacobucci, and B.W. Shirley. 1996. A null mutation in the first enzyme in flavonoid biosynthesis does not affect male sterility in Arabidopsis. Plant Cell 8:1013-1025.

Caltagirone, S., C. Rossi, A. Poggi, F.O. Ranelletti, P.G. Natali, M. Brunetti, F.B. Aiello, and M. Piantelli. 2000. Flavonoids apigenin and quercetin inhibit melanoma growth and metastatic potential. Intl. J. Cancer 87:595-600.

Colliver, S., A. Bovy, G. Collins, S. Muir, S. Robinson, R. Devos, and M. Verhoeyen. 2002. Improving the nutritional content of tomatoes through reprogramming their flavonoid biosynthetic pathway. Phytochem. Rev. 1:113-123.

Estiarte, M., J. Peulas, B.A. Kimball, D.L. Hendrix, P.J. Pinter, Jr., G.W. Wall, R.L. LaMorte, and D.J. Hunsaker. 1999. Free-air $\mathrm{CO}_{2}$ enrichment of wheat: Leaf flavonoid content throughout the growth cycle. Physiol. Plant. 105:423-433.

Ferry, D.R., A. Smith, J. Malkhandi, D.W. Fyfe, P.G. de Takats, D. Anderson, J. Baker, and D.J. Kerr. 1996. Phase I clinical trial of the flavonoid quercetin: Pharmacokinetics and evidence for in vivo tyrosine kinase inhibition. Clin. Cancer Res. 2:659668.

Gabor, M. 1981. Biochemical, cellular, and medicinal properties, p. 1-15. In: Alan, R. (ed.). Flavonoids in biology and medicine II. Liss, New York, NY.

Harborne, J.B. and C.A. Williams. 2000. Advances in flavonoid research since 1992. Phytochemistry 55:481-504.
Harnly, J.M., R.F. Doherty, G.R. Beecher, J.M. Holden, D.B. Haytowitz, S. Bhagwat, and S. Gebhardt. 2006. Flavonoid content of U.S. fruits, vegetables, and nuts. J. Agr. Food Chem. 54:9966-9977.

Hertog, M.G.L., P.C.H. Hollman, and D.P. Venema. 1992. Optimization of a quantitative HPLC determination of potentially anticarcinogenic flavonoids in vegetables and fruits. J. Agr. Food Chem. 40:1591-1598.

Hines, E. 1999. New nutritive substances: Beyond the ABCs. Food Quality 6:39-43.

Huang, Y.T., J.J. Hwang, P.P. Lee, F.C. Ke, J.H. Huang, C.J. Huang, C. Kandaswami, E. Middleton, Jr., and M.T. Lee. 1999. Effects of luteolin and quercetin, inhibitors of tyrosine kinase, on cell growth and metastasis-associated properties in A431 cells overexpressing epidermal growth factor receptor. Brit. J. Pharmacol. 128:9991010.

Jaakola, L., K. Määtta-Riihinen, S. Kärenlampi, and A. Hohtola. 2004. Activation of flavonoid biosynthesis by solar radiation in bilberry (Vaccinium myrtillus L.) leaves. Planta 218:721-728.

Jovanovic, S.V., S. Steenken, M. Tosic, B. Marjanovic, and M.G. Simic. 1994. Flavonoids as antioxidants. J. Amer. Chem. Soc. 116:4846-4851.

Kachlicki, P., L. Marczak, L. Kerhoas, J. Einhorn, and M. Stobiecki. 2005. Profiling isoflavone conjugates in root extracts of lupine species with LC/ESI/MS ${ }^{n}$ systems. J. Mass Spectrom. 40:10881103.

Konczak-Islam, I., M. Yoshimoto, D.X. Hou, N. Terahara, and O. Yamakawa. 2003. Potential chemopreventative properties of anthocyanin-rich aqueous extracts from in vitro produced tissue of sweetpotato (Ipomoea batatas L.). J. Agr. Food Chem. 51:59165923.

Markaverich, B.M., R.R. Gregory, M. Alejandro, F.S. Kittrell, D. Medina, J.H. Clark, M. Varma, and R.S. Varma. 1990. Methyl phydroxyphenyl lactate and nuclear type II binding sites in malignant cells: Metabolic fate and mammary tumor growth. Cancer Res. 50:1470-1478.

Menon, L.G., R. Kuttan, and G. Kuttan. 1995. Inhibition of lung metastasis in mice induced by B16 Flo melanoma cells by polyphenolic compounds. Cancer Lett. 95:221-225.

Moriguchi, T., M. Kita, Y. Tomono, T. Endo-Inagaki, and M. Omura. 2001. Gene expression in flavonoid biosynthesis: Correlation with flavonoid accumulation in developing citrus fruit. Physiol. Plant. 111:66-74.

Peter, N.K., J.W. Frost, and S.R. Long. 1986. A flavones induces expression of Rhizibium metiloti nodulation genes. Science 233:977980.

Rhodes, M. and K.R. Price. 1999. Phytochemicals: Classification and occurrence, p. 1539-1549. In: Sadler, M.J., J.J. Strain, and B. Caballero (eds.). Encyclopedia of human nutrition. Academic Press/Harcourt Brace, New York, NY.

Rice-Evans, C.A., N.J. Miller, and G. Paganga. 1997. Antioxidant properties of phenolic compounds. Trends Plant Sci. 2:152159.

Robards, K. and M. Antolovich. 1997. Analytical chemistry of fruit bioflavonoids: A review. Analyst (Lond.) 122:11R-34R.

U.S. Department of Agriculture. 1989. PI531116. 1 June 2007. <http:// www.ars-grin.gov/cgibin/npgs/acc/display.pl?1426052>.

U.S. Department of Agriculture. 1993a. PI566662. 1 June 2007. <http://www.ars-grin.gov/cgibin/npgs/acc/display.pl? $1461633>$.

U.S. Department of Agriculture. 1993b. PI566646. 1 June 2007. $<$ http://www.ars-grin.gov/cgibin/npgs/acc/display.pl?1461617>.

U.S. Department of Agriculture. 1993c. PI566632. 1 June 2007. $<$ http://www.ars-grin.gov/cgibin/npgs/acc/display.pl?1461603>.

U.S. Department of Agriculture. 1993d. PI566625. 1 June 2007. $<$ http://www.ars-grin.gov/cgibin/npgs/acc/display.pl?1461596>.

U.S. Department of Agriculture. 1993e. PI566613. 1 June 2007. <http://www.ars-grin.gov/cgibin/npgs/acc/display.pl? 1461584>. 
U.S. Department of Agriculture. 2000. PI612703. 1 June 2007. <http:// www.ars-grin.gov/cgibin/npgs/acc/display.pl?1594446>.

U.S. Department of Agriculture. 2003. USDA database for the flavonoid content of selected foods. 15 July 2005. <http://www.nal. usda.gov/fnic/foodcomp/Data/Flav/flav.pdf>.

U.S. Department of Agriculture. 2004. PI634399. 1 June 2007. <http:// www.ars-grin.gov/cgibin/npgs/acc/display.pl?1011123>.

Vickery, H.B., E.M. Nelson, H.J. Almquist, and C.A. Elvehjem. 1950. Term 'vitamin P' recommended to be discontinued. Science 112:628.
Wang, S.P. and K.J. Huang. 2004. Determination of flavonoids by high performance liquid chromatography and capillary electrophoresis. J. Chromatography 1032:273-279.

Weisshaar, B. and G.I. Jenkins. 1998. Phenylpropanoid biosynthesis and its regulation. Curr. Opin. Plant Biol. 1:251-257.

Winke-Shirley, B. 2002. Biosynthesis of flavonids and effect of stress. Curr. Opin. Plant Biol. 5:218-223.

Woolfe, J.A. 1992. Sweetpotato: An untapped food resource. Cambridge, New York, NY. 